\title{
ACUTE RESPIRATORY DISTRESS SYNDROME CAUSED BY METHADONE SYRUP
}

\author{
Abbas AGHABIKLOOEI ${ }^{1}$, Shahin SHADNIA ${ }^{2}$, Hossein HASSANIAN-MOGHADDAM ${ }^{2}$, \\ and Nasim ZAMANI ${ }^{2}$
}

Firoozgar Teaching Hospital, Iran University of Medical Sciences ${ }^{1}$, Department of Clinical Toxicology, Loghman Hakim Hospital, Shahid Beheshti University of Medical Sciences', Tehran, Iran

\author{
Received in January 2013 \\ Cross Checked in May 2013 \\ Accepted in June 2013
}

\begin{abstract}
Acute respiratory distress syndrome (ARDS) due to methadone (MTD) toxicity is a known but rather uncommon phenomenon. In most of the previously reported cases of MTD-related ARDS, MTD was ingested orally in the form of tablets in high or unknown amounts. Despite the findings from the available literature, this case report is aimed at demonstrating that even small amounts of MTD syrup can cause ARDS earlier than it is usually expected. We present a non-addicted MTD-overdosed patient who developed ARDS after ingesting a very small amount of MTD syrup. We suggest close monitoring of MTD-overdosed patients from at least $48 \mathrm{~h}$ to $72 \mathrm{~h}$ for possible respiratory complications such as pulmonary oedema.
\end{abstract}

KEY WORDS: accidental intoxication, overdose, pulmonary oedema, respiratory complications

Methadone (MTD) is a long-acting synthetic opioid receptor agonist with potent analgesic effects. It is commonly used for detoxification or as a substitute in the treatment of opium-addicted patients (1-3). The clinical advantages of MTD lie in its ability to suppress the symptoms of heroin withdrawal, which makes it effective in reducing mortality and morbidity rates among heroin abusers (4). However, it is also potentially toxic, especially in non-tolerant people. Methadone in the form of tablets, if ingested orally, absorbs well and produces a peak plasma concentration within six to twelve hours, which may last for more than $72 \mathrm{~h}$ after a single oral dose (5). It is metabolized in the liver with an average elimination half-life of $25 \mathrm{~h}$ (6). MTD has variant isomers (S, D, and Risomer), but the most commonly used variation is its racemic type (mixture of D and $\mathrm{S}$ forms) $(7,8)$. These isomers have different pharmacokinetics including different volumes of distribution and elimination halflives.
Acute respiratory distress syndrome (ARDS) is a known but uncommon MTD-related phenomenon that has already been reported in the literature (9-11). However, in most cases, methadone was ingested orally in the form of tablets in high or unknown amounts (12). This case report presents a non-addicted patient who developed ARDS after an overdose with MTD syrup.

\section{CASE REPORT}

A non-opioid-dependent 26-year-old woman was referred to our emergency department (ED) in a coma. The patient's spouse had been enrolled in an opioid detoxification program that prescribed the use of MTD syrup. The patient had accidentally swallowed about $10 \mathrm{~mL}$ of MTD syrup (containing $5 \mathrm{mg} \mathrm{mL}^{-1}$ of MTD) $2 \mathrm{~h}$ before being admitted to hospital. On arrival, she 
did not respond to pain stimuli and had pinpoint pupils and bradypnoea, but had no cyanosis or signs of respiratory distress. During her initial examination, her blood pressure was 100/75 $\mathrm{mm} \mathrm{Hg}$, pulse rate was $74 \mathrm{bpm}$, respiratory rate was 9 breaths per minute, and temperature was $36.8^{\circ} \mathrm{C}$. Blood glucose levels (determined by bedside glucometry), electrolytes, and renal function tests were all within normal limits. First arterial blood gas $(\mathrm{ABG})$ analysis showed mild respiratory acidosis due to hypoventilation $(\mathrm{pH}=7.29$, $\mathrm{PaCO}_{2}=49 \mathrm{~mm} \mathrm{Hg}, \mathrm{PaO}_{2}=72 \mathrm{~mm} \mathrm{Hg}, \mathrm{HCO}_{3}=23.8 \mathrm{mEq}$ $\mathrm{dL}^{-1}$, and $\mathrm{O}_{2} \mathrm{Sat}=91 \%$ ). Initial chest $\mathrm{X}$-ray and electrocardiogram were both normal. There were no signs of head trauma or focal neurologic signs. Urine toxicology was positive for methadone. The patient recovered after initial supportive care including airway maintenance, $\mathrm{O}_{2}$ therapy $\left(7 \mathrm{~L} \mathrm{~min}^{-1}\right.$ nasal), and a bolus dose of $1.2 \mathrm{mg}$ of intravenous naloxone to reverse the signs and symptoms of hypoventilation. The patient completely regained consciousness and her respiratory rate increased to 18 breaths per minute. Meanwhile, pulse oximetry showed oxygen saturation to be $93 \%$. Three hours after admission, the patient was transferred to the intensive care unit (ICU) for cardiac monitoring and pulse-oximetry. She received a maintenance dose of IV naloxone $(0.8 \mathrm{mg}$ in $1000 \mathrm{~mL}$ half normal saline with a rate of $100 \mathrm{~mL} \mathrm{~h}^{-1}$ ) to prevent the recurrence of hypoventilation. Within the first ten hours after admission, she fully recovered.

About seven hours after admission to the ICU $(10 \mathrm{~h}$ after admission to the ED), she began to experience gradual respiratory distress, sweating, mild agitation, and had diffuse fine inspiratory crackles in both lungs at auscultation. ABG showed hypoxia $\left(\mathrm{PaO}_{2}=\right.$ $60 \mathrm{~mm} \mathrm{Hg}$ ) and oxygen saturation of $82 \%$ as well as a $\mathrm{Fio}_{2} / \mathrm{PaO}_{2}$ ratio of less than 200. A chest X-ray revealed diffuse bilateral patchy infiltrations. Central vein pressure was within normal range $\left(16 \mathrm{~cm} \mathrm{H}_{2} \mathrm{O}\right)$. The patient was intubated and ventilated with positive end expiratory pressure (PEEP) of $7 \mathrm{~cm} \mathrm{H}_{2} \mathrm{O}$ for $8 \mathrm{~h}$. About $18 \mathrm{~h}$ after admission ( $8 \mathrm{~h}$ after the development of ARDS), she completely recovered, oxygenation was normalized, and she was extubated. She was discharged from the hospital in good condition $22 \mathrm{~h}$ after the extubation.

\section{DISCUSSION}

As MTD half-life varies between $25 \mathrm{~h}$ and $52 \mathrm{~h}$, the signs and symptoms of an overdose can manifest late, prolonging the clinical course of the toxicity (13). These signs and symptoms usually occur within $6 \mathrm{~h}$ to $12 \mathrm{~h}$; however, this varies depending on the MTD variant (14).

In the patient from this case report, the triad of opioid toxidrome appeared about $2 \mathrm{~h}$ after ingestion. This may suggest that the signs and symptoms of an overdose appear earlier in subjects who overdose on MTD syrup than in subjects who consume tablets. In a study by LoVecchio et al. (15), an acute MTD overdose resulted in symptoms within $9 \mathrm{~h}$ of ingestion and all of the symptoms were resolved within $24 \mathrm{~h}$. Clark and Milory (13) showed that MTD toxicity was more likely in those who try the drug for the first time, before developing any tolerance. Although a definite toxic dose in non-addicted people has not been set, an ingestion of $800 \mathrm{mg}$ could be fatal (16). As little as $40 \mathrm{mg}$ to $50 \mathrm{mg}$ may produce loss of consciousness and bradypnoea (17), while in non-tolerant adults, $100 \mathrm{mg}$ can cause life-threatening poisoning (18) due to respiratory arrest.

Our patient was in a coma and had bradypnoea $\left(\mathrm{RR}<10 \mathrm{~min}^{-1}\right)$ after ingesting $50 \mathrm{mg}(10 \mathrm{~mL})$ of MTD syrup, responding dramatically to a prescription of naloxone. This is in accordance with the results of studies by Zyroff et al. (19) and Garden et al. (20), who stated that $40 \mathrm{mg}$ of MTD can lead to a coma and respiratory compromise in non-addicted people. No author has, however, specified the exact MTD dose that leads to non-cardiogenic pulmonary oedema.

In our patient, $50 \mathrm{mg}$ of a mixture of MTD isomer D \& S-form led to ARDS, an uncommon complication for this type of overdose reported only in a few papers $(12,18,21)$ but involving MTD tablets. The pathophysiology of ARDS after an opioid overdose has not been clearly defined, but the direct toxicity of the drug, as well as hypoxia, acidosis, and increased capillary permeability (pulmonary capillary leak) are the most probable mechanisms $(20,22)$. In most cases of MTD-related ARDS, the possible mechanism is hypoxia; however, in our patient, no profound or prolonged hypoxia existed before the development of ARDS. We therefore believe that the mixture of the D \& S-form led to ARDS through direct toxicity on the lung parenchyma.

ARDS can affect the future course of treatment. Corkery et al. (2) stated that ARDS, respiratory depression, and aspiration pneumonia are the main causes of morbidity and mortality in MTD-overdosed patients. Several studies have shown that MTD-related deaths occur rather frequently in subjects undergoing 
rehabilitation $(23,24)$. Among a total of 1120 deaths due to opioid overdose, $12.8 \%$ were MTD-related and ARDS could have well had an important role (25). Patients suffering from ARDS experience severe dyspnoea accompanied by hypoxemia and exhibit diffuse infiltration in chest radiographs (bilateral alveolar filling pattern). In our case, a pulmonary oedema was established about 12 hours after ingestion, which is in contrast to a study by Presant et al. (21), who found that ARDS did not develop until $24 \mathrm{~h}$ after the overdose. MTD-related ARDS often requires a period of invasive mechanical ventilation depending on its severity and fortunately, most cases are selflimited with rapid resolution by assisted ventilation such as PEEP or continuous positive airway pressure (CPAP) (12). Ridgway and Pountney (12) reported that, in ARDS secondary to MTD overdoses, early non-invasive respiratory supportive methods such as bi-level positive airway pressure (BiPAP) via a facemask might reduce the need for invasive ventilation. Our patient fully recovered after $8 \mathrm{~h}$ of mechanical ventilation with PEEP $\left(7 \mathrm{~cm} \mathrm{H}_{2} \mathrm{O}\right)$, which is in accordance with the results of Sporer and Dorn (26), who stated that $33 \%$ of MTD patients would need mechanical ventilation in less than $24 \mathrm{~h}$. We successfully treated our patient with naloxone and applied PEEP. It should be emphasized that opiate antagonists such as naloxone reverse central nervous system and respiratory depression but do not correct opiate-induced pulmonary oedemas (27). This case also showed that MTD syrup-related ARDS (racemic type; a mixture of D \& S forms) can occur with low doses of the drug, which is in contrast to previous claims that these complications occur after severe overdoses (28). MTD syrup responds to mechanical ventilation faster than the other preparation forms of this drug (e.g., MTD tablets). Although in our case ARDS occurred within a few hours after the intoxication, some authors believe that the occurrence of ARDS may be delayed due to recurrent respiratory arrest and hypoxia. They have therefore recommended that MTD-overdosed patients should be closely monitored at hospital for $72 \mathrm{~h}$ because of the risk of pulmonary oedema (28).

\section{CONCLUSION}

In general, this case is different from other MTD overdose cases available in the literature, because ARDS occurred with lower doses of MTD syrup (in comparison with MTD tablets). It also showed that ARDS occurred even after signs of toxicity had improved with naloxone and the patient became asymptomatic. Thus, we believe that opioid-naïve patients with acute MTD intoxication should be observed for at least $48 \mathrm{~h}$ to $72 \mathrm{~h}$ for possible occurrences of ARDS due to the prolonged elimination half-life of MTD.

\section{CONFLICT OF INTEREST}

None declared.

\section{REFERENCES}

1. Anggard E, Nilsson MI, Holmstrand J, Gunne LM. Pharmacokinetics of methadone during maintenance therapy: pulse labeling with deuterated methadone in the steady state. Eur J Clin Pharmacol 1979;16:53-7. PMID: 499301

2. Corkery JM, Schifano F, Ghodse AH, Oyefeso A. The effects of methadone and its role in fatalities. Hum Psychopharmacol 2004;19:565-76. doi: 10.1002/hup.630

3. Hendra TJ, Gerrish SP, Forrest AR. Fatal methadone overdose. BMJ 1996;313:481-2. doi: 10.1136/ bmj.315.7099.55a

4. Reingardiene D, Jodziūniene L, Lazauskas R. [Methadone treatment and its dangers, in Lithuanian]. Medicina (Kaunas) 2009;45:419-25. PMID: 19535889

5. Olsen GD, Wendel HA, Livermore JD, Leger RM, Lynn RK, Gerber N. Clinical effects and pharmacokinetics of racemic methadone and its optical isomers. Clin Pharmacol Ther 1977;21:147-57. PMID: 837634

6. Vazquez V, Gury C, Laqueille X. [Methadone: from pharmacokinetic profile to clinical pharmacology, in French]. Encephale 2006;32:478-86. PMID: 17099560

7. Eap CB, Finkbeiner T, Gastpar M, Scherbaum N, Powell K, Baumann P. Replacement of (R)-methadone by a double dose of $(\mathrm{R}, \mathrm{S})$-methadone in addicts: interindividual variability of the $(\mathrm{R}) /(\mathrm{S})$ ratios and evidence of adaptive changes in methadone pharmacokinetics. Eur J Clin Pharmacol 1996;385:50-9. doi: 10.1007/s002280050128

8. Rostami-Hodjegan A, Wolff K, Hay AW, Raistrick D, Calvert R, Tucker GT. Population pharmacokinetics of methadone in opiate users: characterization of time dependent changes. Br J Clin Pharmacol 1999;48:43-52. doi: 10.1046/j.13652125.1999.00974.x

9. Drudi FM, Poggi R, Trenta F, Manganaro F, Iannicelli E. [A case of the adult respiratory distress syndrome induced by a methadone overdose, in Italian]. Radiol Med 1997;94:393-6. PMID: 9465250

10. Schaaf JT, Spivack ML, Rath GS, Snider GL. Pulmonary edema and adult respiratory distress syndrome following methadone abuse. Am Rev Respir Dis 1973;107:1047-51. PMID: 4740265

11. Martin M, Daoudal P, Bein C, Bazzi N, Bourscheid D, Floriot C. [Inhaled methadone-induced non cardiogenic pulmonary 
edema with Acute Respiratory Distress Syndrome, in French] Presse Med 2011;40:436-8. doi: 10.1016/j. lpm.2010.11.017

12. Ridgway ZA, Pountney AJ. Acute respiratory distress syndrome induced by oral methadone managed with noninvasive ventilation. Emerg Med J 2007;24:681. PMID: 17711964

13. Clark JC, Milroy CM, Forrest AR. Deaths from methadone use. J Clin Forensic Med 1995;2:143-4. PMID: 15335644

14. Sporer KA. Acute heroin overdose. Ann Intern Med 1999;130:584-90. PMID: 10189329

15. LoVecchio F, Pizon A, Riley B, Sami A, D'Incognito C. Onset of symptoms after methadone overdose. Am J Emerg Med 2007;25:57-9. PMID: 17157684

16. Shannon MW, Borron SW, Burns MJ. Opioid overdose. In: Shannon MW, Borron SW, Burns MJ, editors. Haddad and Winchester's Clinical Management of Poisoning and Drug Overdose. $4^{\text {th }}$ ed. Philadelphia (PA): Saunders Elsevier; 2007. p. 645-7.

17. Garriott JC, Sturner WQ, Mason MF. Toxicologic findings in six fatalities involving methadone. Clin Toxicol 1973;6:163-73. PMID: 4715200

18. Harding-Pink D. Methadone: one person's maintenance dose is another's poison. Lancet 1993;341:665-6. PMID: 8095576

19. Zyroff J, Slovis TL, Nagler J. Pulmonary edema induced by oral methadone. Radiology 1974;112:567-8. doi: 10.1148/112.3.567

20. Gordon E. Treatment of methadone poisoning. JAMA 1972;220:728-31. doi: 10.1001/jama.1972. 03200050066028
21. Presant S, Knight L, Klassen G. Methadone-induced pulmonary edema. Can Med Assoc J 1975;113:966-7. PMID: 1192314

22. Wilson KC, Saukkonen JJ. Acute respiratory failure from abused substances. J Intensive Care Med 2004;19:183-93. doi: $10.1177 / 0885066604263918$

23. Marks J. Deaths from methadone and heroin. Lancet 1994;343:976. doi: 10.1016/S0140-6736(94)90100-7

24. Drummer OH, Opeskin K, Syrjanen M, Cordner SM. Methadone toxicity causing death in ten subjects starting on a methadone maintenance program. Am J Forensic Med Pathol 1992;13:346-50. PMID: 1288269

25. Shah N, Lathrop SL, Landen MG. Unintentional methadonerelated overdose death in New Mexico (USA) and implications for surveillance, 1998-2002. Addiction 2005;176:88-100. doi: 10.1111/j.1360-0443.2004.00956.x

26. Sporer KA, Dorn E. Heroin-related noncardiogenic pulmonary edema: a case series. Chest 2001;120:1628-32. doi: 10.1378/chest.120.5.1628

27. Bradberry JC, Raebel MA. Continuous infusion of naloxone in the treatment of narcotic overdose. Drug Intell Clin Pharm 1981;15:945-50. PMID: 7338189

28. Fraser VJ, Burd L, Liebson E, Lipschik GY, Peterson CM. Respiratory system disorders. In: Fraser VJ, Burd L, Liebson E, Lipschik GY, Peterson CM, editors. Diseases and disorders. New York (NY): Marshal Cavendish Corp; 2007. p. 713-22. 


\section{Sažetak}

\section{AKUTNI RESPIRATORNI DISTRES SINDROM UZROKOVAN SIRUPOM METADONA}

Akutni respiratorni distres sindrom (ARDS) uzrokovan toksičnošću metadona (MTD) poznat je ali rijedak fenomen. U većini dosadašnjih slučajeva ARDS-a uzrokovanog MTD-om, MTD je konzumiran u obliku tableta te u velikoj ili nepoznatoj količini. Unatoč nalazima dostupne literature, ovaj prikaz slučaja dokazuje kako čak i mala količina sirupa MTD-a može uzrokovati ARDS, i to ranije nego što bi se očekivalo. Obrađen je slučaj pacijentice koja nije bila ovisnica, a oboljela je od ARDS-a nakon konzumacije tek male količine sirupa MTD-a. Predlažemo pomnije praćenje pacijenata predoziranih MTD-om od najmanje 48 sati do 72 sata usmjereno na detekciju respiratornih komplikacija poput plućnih edema.

KLJUČNE RIJEČI: plućni edem, predoziranje, respiratorne komplikacije, slučajna intoksikacija

\section{CORRESPONDING AUTHOR:}

Nasim Zamani, MD

Department of Clinical Toxicology

Loghman Hakim Hospital

Karegar Street, Tehran, Iran

E-mail: nasim.zamani@gmail.com 